\title{
Studi Pengelolaan Limbah B3 di RSUD dr Drajat Prawiranegara Kabupaten Serang
}

\author{
Ade Ariesmayana ${ }^{1, *}$, Hajali ${ }^{2}$ \\ 1,2, Program Studi Teknik Lingkungan, Fakultas Teknik,Universitas Banten Jaya \\ Jalan Ciwaru II No.73 Kota Serang \\ *Koresponden email: adeariesmayana@unbaja.ac.id
}

Diterima: 23 Mei 2018

Disetujui: 29 Agustus 2018

\begin{abstract}
The purpose of this study was to describe the B3 waste management system in the District General Hospital dr. Drajat Prawiranegara Serang District 2016, identifying the sources and characteristics of B3 waste in their respective sources of waste in the District General Hospital dr. Drajat Prawiranegara Serang District with existing standards. This study uses observation. Collecting data using systematic observation techniques, while in-depth analysis of the data processed by qualitative techniques to describe the efforts pengelolahan hazardous wastes and toxic B3 at Regional General Hospital dr. Drajat Prawiranegara Serang District were then compared with BAPEDAL regulation No. 01/05 / 1995. The results showed the Regional General Hospital dr, Serang regency degrees Prawiranegara produce volumes of hazardous and toxic waste. Efforts management of hazardous wastes and toxic B3 of the lug or packaging, storage, transportation done well.
\end{abstract}

Keywords: Hazardous and Toxic (B3), Hospital waste management

Abstrak. Tujuan penelitian ini adalah untuk mendeskripsikan sistem pengelolaan limbah B3 di Rumah Sakit Umum Daerah dr. Drajat Prawiranegara Kabupaten Serang Tahun 2016, mengidentifikasikan sumber dan karakteristik limbah B3 pada masing-masing sumber limbah di Rumah Sakit Umum Daerah dr. Drajat Prawiranegara Kabupaten Serang dengan standar yang ada. Penelitian ini menggunakan metode observasi. Pengumpulan data menggunakan teknik observasi sistematis mendalam sedangkan analisis data diolah dengan teknik kualitatif untuk menggambarkan upaya pengelolahan limbah bahan berbahaya dan beracun B3 di Rumah Sakit Umum Daerah dr. Drajat Prawiranegara Kabupaten Serang yang selanjutnya dibandingkan dengan peraturan Bapedal No 01/05/tahun 1995. Hasil penelitian menunjukan Rumah Sakit Umum Daerah dr, Drajat Prawiranegara kabupaten Serang menghasilkan volume limbah bahan berbahaya dan beracun.Upaya pengelolaan limbah bahan berbahaya dan beracun B3 dari pewadahan atau pengemasan, penyimpanan, pengangkutan dilakukan dengan baik.

Kata kunci: Limbah B3, manajemen limbah Rumah Sakit, limbah rumah sakit

\section{Pendahuluan}

Meningkatnya kegiatan pembangunan di Indonesia dapat mendorong peningkatan pembangunan bahan berbahaya dan beracun B3 di berbagai sektor seperti industri, pertambangan, pertanian dan kesehatan. B3 tersebut dapat berasal dari dalam negeri maupun luar negeri (impor). B3 yang dihasilkan dari dalam negeri juga ada yang diekspor ke suatu negara tertentu. Proses ekspor dan impor ini semakin mudah untuk dilakukan dengan masuknya era globalisasi.
Selama tiga dekade terakhir, penggunaan bahan berbahaya dan beracun B3, seperti limbah bahan kimia kadaluwarsa di Indonesia semakin meningkat dan tersebar luas di semua sektor apabila tidak dikelola dengan baik, maka dapat menimbulkan kerugian terhadap kesehatan manusia, makhluk hidup dan lingkungan hidup, seperti pencemaran udara, tanah, air dan laut (PP No 74 tahun 2001).

Rumah Sakit menyelenggarakan upaya pelayanan kesehatan meliputi pelayanan rawat 
jalan, rawat inap, pelayanan gawat darurat, pelayanan medis dan non medis proses kegiatan tersebut akan dapat menimbulkan dampak positif dan negatif. Oleh karena itu perlu upaya penyehatanlingkungan rumah sakityang bertujuan untuk melindungi masyarakat dan petugas Rumah Sakit dari bahaya pencemaran lingkungan yang bersumber dari limbah Rumah Sakit. Rumah sakit merupakan salah satu penghasil limbah B3 yang ditimbulkan dari seluruh aktivitas rumah sakit seperti bahan tambahan untuk pencucian luka, cucian darah praktek bedah, produk farmasi.

Pada survey awal yang dilakukan pada bulan maret tahun 2012, di Rumah Sakit Umum Daerah dr. Drajat Prawiranegara Kabupaten Serang, pembuangan botol ampul masih ditaruh didalam jeregen bekas atau tempat infus yang sudah tak terpakai. Pengelolaan limbah B3 Rumah Sakit Umum Daerah dr. Drajat Prawiranegara masih mengalami masalah dalam pengelolaan limbah benda tajam khususunya bekas ampul dan jarum suntik.

\section{Metode Penelitian}

Dalam hal ini penelitian dilakukan dengan mengamati secara fisik (survey) dan kimia serta menilai sejauh mana pelaksanaan studi pengelolaan limbah berbahaya dan beracun B3 di RSUD dr. Drajat Prawiranegara Kabupaten Serang Tahun 2016 berjalan disertai dengan adanya pengolaan sesuai peraturan serta sistem pengelolaan yang dilakukan.

Adapun tahapan - tahapan penelitian adalah sebagai berikut:

a. Tahapan Persiapan

1. Melaksanakan observasi awal untuk mendapatkan data awal tentang banyaknya limbah medis padat yang dihasilkan dan pengelolaan limbah medis padat di Rumah Sakit Umum Daerah dr. Drajat Prawiranegara Kabupaten Serang.

2. Menyusun instrumen yaitu formulir pengukuran volume limbah medis padat, tata cara dan persyaratan teknis penyimpanan dan pengumpulan limbah medis padat petugas Instalasi sanitasi lingkungan rumah sakit dr. Drajat Prawiranegara Kabupaten Serang

b. Tahapan Pelaksanaan.

Pelaksanaan penelitian dengan tahapan sebagai berikut:

1. Mendata petugas terkait yang berhubungan dengan limbah medis padat.

2. Mencatat jadwal petugas pengambilan limbah medis padat.

3. Peneliti bersama petugas terkait pengambil limbah medis padat dan mencatat hasil limbah yang dihasilkan di setiap ruangan.

4. Peneliti bersama petugas sanitasi melakukan penimbangan limbah medis padat dan di lanjutkan dengan penyimpanan sementara limbah medis padat.

5. Hasil dari pengukuran dibandingkan dengan Keputusan Kepala Bapedal No.1-5/09/1995.

6. Membuat kesimpulan berdasarkan hasil analisis data yang di peroleh.

\section{Hasil dan Pembahasan}

\subsection{Karakteristik limbah bahan berbahaya dan beracun (B3)}

Limbah bahan berbahaya dan beracun B3 di Rumah Sakit Umum Daerah dr. Drajat Prawiranegara Kabupaten Serang berasal dari tindakan medis yang dilakukan antara lain kegiatan perawatan pasien baik rawat inap maupun rawat jalan, kegiatan laboratoruim, radiologi bedah maupun kegiatan di ruang farmasi, sebagian besar limbah bahan berbahaya dan beracun B3 yang di hasilkan berupa alat atau bahan yang terkena reagen kimia yang di gunakan di laboratarium dan sisa-sisa obat-obatan kadaluwarsa, untuk lebih jelasnya dapat dilihat dalam Tabel 1, 2 dan 3 berikut:

Berdasarkan Tabel 3 penelitian di bulan Mei 2016 jumlah sampah yang dihasilkan sebanyak $7.830 \mathrm{~kg}$, bulan Juni 2016 sebanyak $7.438 \mathrm{~kg}$ dan bulan Juli 2106 sebanyak $7.375 \mathrm{~kg}$ rata-rata volume per bulan untuk mengetahui pengelolaan limbah medis padat di RSUD dr. Drajat Prawiranegara Kabupaten Serang. Berdasarkan hasil dari penelitian ini dapat di ketahui pengelolaan sampah medis di RSUD dr. Drajat Prawiranegara 
Tabel 1. Sumber dan karakteristik limbah B3 di RSUD dr. Drajat Prawiranegara

\begin{tabular}{|c|c|c|}
\hline$\checkmark n$. & Ieniz kegiatan & I.minalı yang diluasilkan \\
\hline 1 & $\begin{array}{l}\text { Insialasi } \\
\text { libboralorium }\end{array}$ & $\begin{array}{l}\text { Tabun!y alau trotol bekas, jarun suntik. kupas, dan } \\
\text { kisssa bekils. }\end{array}$ \\
\hline 2 & lnstalasi firmasi & $\begin{array}{l}\text { Ohar- olxatan kadalux'arsa, makkcr; sarung tangan, } \\
\text { falksin }\end{array}$ \\
\hline 3 & Instalasi radiolny & 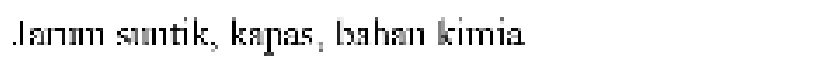 \\
\hline 4 & Rawat jalan & Iarum suntik, kapas, kassa bckas \\
\hline 5 & Rowat inap & Jarum suntik, kapas, hassi bekas. \\
\hline 6 & Hemodialisa & $\begin{array}{l}\text { Jarum sumtik, selunge (arteri dan vena). plester bekas, } \\
\text { kapas, kassa bekas. }\end{array}$ \\
\hline 7 & $\begin{array}{l}\text { Intalansi } \\
\text { seularal }\end{array}$ & $\begin{array}{l}\text { Bedah gunting atau pisau, jarum suntik, kapas, kassa } \\
\text { belkas, jaringrid tubul, durala. }\end{array}$ \\
\hline
\end{tabular}

Sumber: Profil Instalasi Sanitasi RSUD dr. Drajat Prawiranegara Kab. Serang

Tabel 2. Karakteristik limbah B3 di RSUD dr. Drajat Prawiranegara

\begin{tabular}{|c|c|c|}
\hline$\searrow_{0}$. & Karakteristik & Bahą (materi) \\
\hline 1 & Infeksius: & $\begin{array}{l}\text { labontonium, bahan yang berkontak dengan pasien } \\
\text { (kassa, tisu, kapas bckas) }\end{array}$ \\
\hline 2 & Patologis & $\begin{array}{l}\text { Oryan atau anggota badan yang diangkat pada } \\
\text { waktu oprasi. daralu, plascntá. }\end{array}$ \\
\hline 3 & Kimia & $\begin{array}{l}\text { pemeriksaan di laboratnrium, seperti IICl: JI, } \mathrm{O} \text {, } \\
\text { formalin }\end{array}$ \\
\hline 4 & Beukdi- bendia lạ̣jan & $\begin{array}{l}\text { Jarum suntik, pecahan gelas. pisau bedah peralatan } \\
\text { infis }\end{array}$ \\
\hline 5 & I.imbah famasi & $\begin{array}{l}\text { Obat-ubatan kakdialuwasa, tempat obal, alcohol, } \\
\text { faksin, sarune tangan, masker }\end{array}$ \\
\hline
\end{tabular}

Kabupaten Serang mulai dari pengumpulan, penyimpanan, pewadahan dan pengangkutan masih perlu penambahan sumber daya manusia (SDM) untuk pengelolaan limbah medis padat. Karena dengan jumlah rata-rata sampah yang dihasilkan perbulan diperlukan SDM yang banyak sehingga proses pengolahannya akan efektif dan efisien. Sedangkan SDM yang tersedia di RSUD dr. Drajat Prawiranegara bagian marketing, bagian umum dan pemeliharaan sarana, bagian sanitasi, kerohanian, dan UPKM. Tidak ada bagian khusus mengelolah limbah B3 padat mulai dari pengumpulan, penyimpanan, pewadahan dan pengangkutan untuk jumlah rata-rata tiap hari yang dihasilkan masih membutuhkan SDM.

\subsection{Evaluasi limbah B3 di RSUD dr. Drajat Prawiranegara}

Tata cara pengemasan limbah B3 di RSUD dr.
Drajat Prawiranegara Kabupaten Serang sudah sesuai dengan peraturan, tidak semua peghasil atau pengumpul sudah mengetahui karakteristik limbah dan dilakukan pengujian terhadap limbah yang dihasilkan, kemasan untuk limbah B3 yang infeksius menggunakan plastik berwarna kuning, sedangkan limbah non medis menggunakan plastik warna hitam.

Pengelolaan limbah bahan berbahaya dan beracun B3 /TPS di rumah sakit umum daerah dr. Drajat Prawiranegara Kabupaten Serang terletak $20 \mathrm{~m}$ dari fasilitas umum yaitu mushola, laundry dan intalasi gizi. Hal tersebut tidak sesuai dengan keputusan kepala Bapedal No. 03/09/95 yang mewajibkan lokasi pengolahan limbah berjarak minimal $50 \mathrm{~m}$ dari fasilitas umum. Pengangkutan limbah B3 Rumah Sakit Umum Daerah Kabupaten Serang hanya bersifat sementara pengangkutan secara rutin 1 minggu $3 \mathrm{x}$ oleh 
Tabel 3. Sumber volume sampah medis B3 di RSUD dr. Drajat Prawiranegara

\begin{tabular}{|c|c|c|c|c|c|}
\hline$\backslash n$ & Bulan & $\begin{array}{c}\text { ח } \\
\text { Yamlah Sihampasilka } \\
\text { perbulan }\end{array}$ & $\begin{array}{c}\text { Rata-Rata } \\
\text { Perhari }\end{array}$ & $\begin{array}{c}\text { h } \\
\text { Medis Yanlah Sampah } \\
\text { Dimusanalbkan }\end{array}$ & Kerclangan \\
\hline 1 & Mei & $7 \times 30 \mathrm{~kg}$ & $252,5 \mathrm{~kg}$ & $7.58 \times \mathrm{kg}$ & $\begin{array}{c}\text { Kirim kc Pl: } \\
\text { Wiustev }\end{array}$ \\
\hline 2 & Juni & $7.438 \mathrm{~kg}$ & $247,9 \mathrm{~kg}$ & $7.717 \mathrm{lg}$ & $\begin{array}{c}\text { Kirim be PT. } \\
\text { Wastec }\end{array}$ \\
\hline 3 & Juli & $7.375 \mathrm{~kg}$ & $245,8 \mathrm{~kg}$ & $7.182 \mathrm{ks}$ & $\begin{array}{c}\text { Kirim be PT. } \\
\text { Wistec }\end{array}$ \\
\hline
\end{tabular}

Sumber: Instalasi sanitasi RSUD dr. Drajat Prawiranegara Kab. Serang

pihak PT. Wastec. Berdasarkan keputusan kepala Bapedal No 03/09/95 mewajibkan pengolah melakukan pemeriksaan rutin setiap minggu. Apabila terjadi tumpahan bahan kimia, bahan penyerap yang dipakai tidak sesuai dengan jenis dan karakteristik limbah.

\subsection{Evaluasi Pengelolaan Limbah B3 di RSUD dr. Drajat Prawiranegara}

1. Evaluasi tata cara dan persyaratan teknis penyimpanan dan pengumpulan

Limbah bahan berbahaya dan beracun

B3 dengan standar acuan Keputusan

Kepala Bapedal No. 01/1995 Rumah Sakit Umum Daerah dr. Drajat Prawiranegara Kabupaten Serang.

a. Menurut keputusan Kepala Bapeda No.

01 tahun 1995 penghasil/pengumpul mengetahui karakteristik bahaya limbah B3 yang dihasikan. Hal tersebut belum sesuai dengan standar karena belum semua penghasil /pengumpul mengetahui karateristik bahaya limbah B3. Perlu ada sosialisasi dari pihak sanitasi akan bahaya limbah B3 kesemua karyawan RSUD dr. Drajat Prawiranegara Kabupaten Serang

b. Menurut Keputusan Kepala Bapedal No. 01 tahun 1995 kemasan tersebut dari plastik logam yang tidak bereaksi dengan limbah B3 lain yang disimpan. Kemasan yang ada di Rumah Sakit Umum Daerah dr. Drajat Prawiranegara Kabupaten Serang sudah sesuai standar acuan.

c. Menurut Keputusan Kepala Bapedal No. 01 tahun 1995 dilakukan

Tabel 4. Evaluasi tata cara dan persyaratan teknis penyimpanan dan pengumpulan limbah B3 di RSUD dr. Drajat Prawiranegara

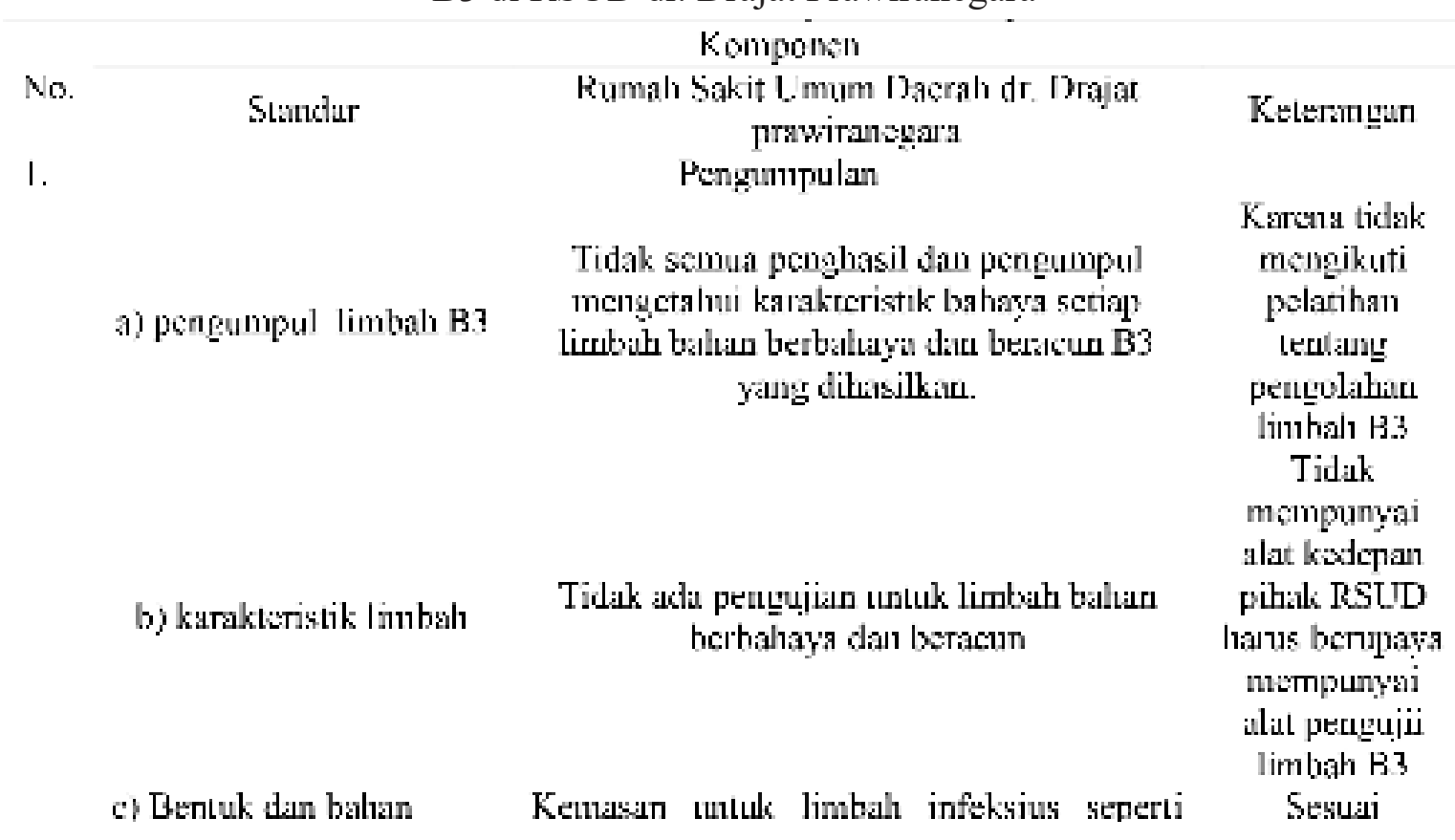


kemasan dipilih berdasarkan kecocokan terhadap jenis dan karakteristik limbah yang di kemas.

2.

a) Kemasan limbah bahan berbahaya dan beracun (B3) dalam kondisi baik, tidak rusak dan bebas dari pengkaratan serta kebocoran.

b) Bentuk, ukuran dan bahan kemasan limbah bahan berbahaya dan beracun B3 sesuai dengan karakteristik limbah B3 yang dikemas dengan memperhatikan segi keamanan dan kemudahan dalam pengelolaan

c) Kemasan terbuat dari bahan plastik dan logam yang tidak breaksi dengan limbah bahan berbahaya dan beracun (B3)

3.

a) Limbah limbah yang tidak cocok disimpan secara bersama sama dalam satu wadah.

b) Jumlah pengisian limbah dalam kemasan mempertimbangkan kemungkinan terjadinya pengembangan

c) Limbah bahan berbahaya dan beracun B3 di pindahkan dalam kemasan lain yang memenuhi syarat apabila yang pertama sudah dalam kondisi yang tidak layak. jarum suntik di taruh dalam safety box, sedangkan limbah B3 yang bersifat infeksius plastik warna kuning dan limbah non medis dalam kantong plastik warna hitam.

\section{Kemasan}

Kemasan limbah infeksius seperti benda tajam ditaruh dalam safety box yang anti rusak.

Sesuai

Kemasan yang dipakai adalah tempat sampah yang terbuat dari plastik yang dapat digunakan kembali dan mudah di bersihkan.

Terbuat dari plastik yang sesuai didalamnya dilapisi plastik warna kuning dan ungu dan tertutup rapat.

\section{Prinsip pengemasan}

Dalam kantong plastik kuning untuk limbah infeksius seperti jaringan tubuh sedangkan plastik warna hitam untuk limbah non medis

Sesuai

Kantong plastik diganti apabila volume limbah mencapai $3 / 4$ bagian dan diikat kuat serta disimpan dalam bak penampungan.

Sesuai

Dipindahkan dalam kantong plastik lain.

Sesuai 
d) Kcmasan yaung telah berisi limbah diberi penandaan 3с5แai kelentuain yungr berlaku

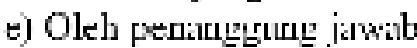
untuk memastikan tidak. terjadi kerusakan alau liebucoran pallas kemasan.

f) Kcgiaral pengemasan, penyimpantan dan pengumpulan dilaporkan schugai haỵim dari kegialian pengelolinu limbah

4.

a) Dalkam kondisi yang baik tidak bocor. berkaral alau rusak

b) Terbuat dari bahan wang cocok dengan karaktoristik limbah

c) Машрu mengiminkinu lumbal yang dismpan di dalamny

d) memiliki pessulup kuat

e) kernasan yan:r diguriakan berupia drumiember dengan volume 50 liter, 100) liler aliau 200 liter diwn berpenutup denpan kapasitas $2 \quad \mathrm{ml}^{2} 4$ maliau $8 \mathrm{~m}$

f) I.imbah yang disimpan dalam kemasan adalalo limbah yanı merrikiki karakteristik sama atau saling cocok

c) Sebelum dimasubian kemasan, limbah dikemass dalem kismtung yang tilain cerhadap sifat limbah

h) Limhali B3 harus memperbulikan ruknuxan untuk pengembangan volume limbal

i) Untuk limbilh Yaner Untuk balkin bilkan yang mudial melediak
Sesuai

dan kantong hiram untuk limbah non medis

Pada waktu mengemas sampai pengelolaan limbuh yanọ dilukukan seliup salu ming̣gu stekili.

Ada laporan sccara tertulis pada bagsian

Instalasi Sanitasi

Scsuai

Persyaralan pengemasian limbah

Kemasian teabuat dari babien plistik dan becon yang baik. tidak bocor, berkarat atan rusak.

terkunci dan memilik penutup yang kuat

Drum alau ember besar yanir dirnanakun mampu menampurig volume 50 liker. bak penampung mempunyan beberapa ukuran antara lain $0,5 \mathrm{ml}$ m,dan $3 \mathrm{~m}$

Scsuai

I imbah modis padat dan limbah padat non medis sudah di pisalikan.

Limbals di kemas dalium kantong plastic

Scsuai

Limbah lanesung di kirim PT. Wastec Intcrnasional

Seruai

Sesuai 
mudah mclodak: dirarul dirnangan talıan asam.

kemasan dinancane

talıan akan kenaikan

tekanan dari dalam dan

luar kemasise.

j) kemasan yang telah

berisi limbah balian

beabubaya dan bericua:

k) Ditandai dengan simbol dan lahel yang sesuni ketcutuan selalu dalam keadaan reıtupup

l) $\mathrm{Di}$ simpan dalum tempat vang. memenuhi syurat.

mi Periksal londisi kemasen seriap minergu

n) Kemastu yang bekas ఛang akan digunakan kembali di euci bersil

o) Kcmasan yang ruzak di perlakukan sebaga linbah B3

5. Pewadahan limbah bahan berbahaya dan beracun 1B3)

6. Penyimpanan limbih bahaก berbahaya san heracun B.3

a) Tilti. penyimpanan kะmasal limbah

เับเ

b) Pencmpatan limbah (B3)

7. Perts

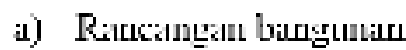
dan luas yang scsuai.

b) T'erlindungi dari hujan.

v) Terdaysat ventilasi dan bisisil dan sclanjumya dikirim Pl. Wastce benıkuran $3 \times 1$ pun bertambah. dalam nuanean tersendiri dilempal beibentuk ruangras
Kemasan limbah di her lahel dan simbol. Sslalu tertutup

Di simpan daliw rudngan penampungan yang terlerak do sehclalı IP'Al.

Tiliak dilakukan pemeriksalian sutin

LIntuk tempat sampals tempat limbah Di euci bersih pakai satunn namun plastik di dalamnya akan dipgemti dengan yuners baru.

Kemasan yang lussak disimpan dalam yudang sodangkan limbalı lokas intis dilinim ke PT. Wastec

I.imbah $B 3$ yane bersităt scsuai infeksius di laruh dalam lempal sampah yangr di lapisis plastik wana kuning dan limbah nun medis dalan plastik warna hitan yang silanjutnya dikirim PT. Westec

Sxuai

Sosuai

Semimgrus ix.

di kirim $\left|{ }^{\prime}\right|$

Waslec

Sesuai

scruai

Sesuai

Sะะuai

disimpan dalam bak penampungan: TPS

Ruanuzan penampungan limbah B3

aratan banguman penvimpanan limbah

TPS cukup unluk menumpune limbeds yang dihasilkan sctiap hari. namun tempat TPS perlu di perluas mengingul runngan rawat inap bertambals tent limbals medis

lerlandungi dari hujal karena posizi tempal penampungan limbah berada di

ada ventilasi karena banụunan di buat

Sesuli bejolian waktu ruang ruwal inup bestimbilh

Sesuai

รсзиเаi 


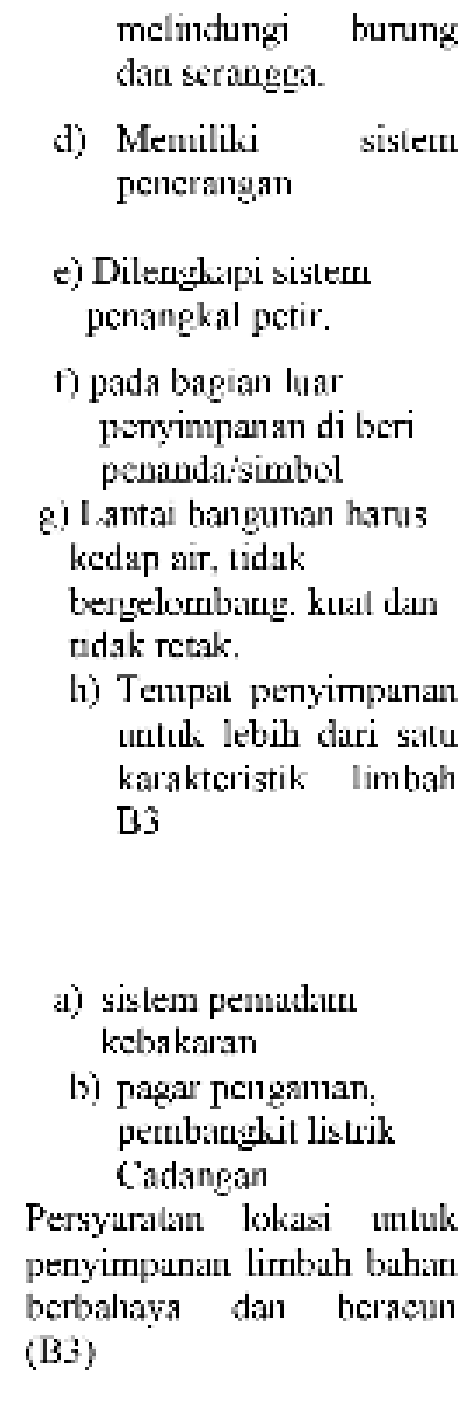

1. Perzyaratan lokasi pengumpulan

a) I.uas tanah termasuk untuk hanỵunan penyimpanin dan fasilitas lannya minimal I IJa.

b) Areal secuara geogralis merugakan dueruh hebus banjị

2. Persyaratan hamgunan pengumpulan merupgakan fasilicas bhusins ada pencrangan dalam ruangan

penkmpungun, penerangan yame di pakai

berasel dari limpu neun

Penang kal perir di rungasa ini tidak ada, namum umluk seluruh bungunun RSUD dr. drạjat prowiramegala Kabupaten Senang

Ada tulisan mudal meledak ditconpar l'PS

Sesuni

Lantai banguman di beri alas palet ber[ungsi air limbals lichali mengurai

Sesuai

Ticluk uda

Pilluk RSLD

harus pelas

duluese

meimperharikan

lisik bunguka

limbah B?

Sarana dan prasarana

Namus menjadi salu dengan bantrunla RSI.I) dr. Imajat Prawirancegara Kabupaten Sicrang.

Sesuม

T'erletak ditempat bebas banjir namun dckar dokat fasilitas umum (intalansi, eiji, launklty dan musholaj

Pengangkutan limbalo modis 1 minggu $3 \mathrm{x}$

Persyaralan pengrupulia limbals medis padat berbahaya dan beracun

Pengangkutan

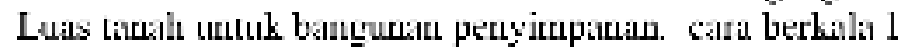
dan lainnya hanya $211 \mathrm{~m}$ mingsu $3 x$

Keleabulidsian

Lobilsi tempial pengumpulan terletiak dckac lasiliacas umum.

lahan dan

pemekaran

ruangian barus

dilakukan

Bangunan pengumpulan hanya satu lempal
Sesuai 
3. Fasilitas tamluahan Luboratoritun

Tasililas pencucian

Fasilitas bonekar muat

Kolam

darural

$$
\text { pchampungan }
$$

Tala uara penyimpanan: pengumpulan

lata cam pengemasan dan pentoumpulan

Tata cara pewadahan
Tidak dilengkapi dengan pencatat dan pentoalur suluu.

lidak

mempunyai

alat dan unouk

kedepan harus

แетприуді

alat

Tidak memiliki laborulurium untuk Tidak adu meneuji jeniz dan karakteristik limbah lasilitas serta pengujian kualitas

Tersedia kran unluk mencuci peralalan.

Ada troli untuk meneangkit limbah

pengujian lab

Sesuai

Sesuai

Ketcrbatazal

luhan

Scรแai

sudah sesuai peraturan

Tatz cara nengemasan sudal scsun

peraluran

Táta cara pewadkanan sudah sesuai ржтаturan

Scsuลai

Sesuai

Sumber: Instalasi Sanitasi RSUD dr. Drajat Prawiranegara Kab. Serang.

Tabel 5. Evaluasi teknis pengelolaan limbah B3 di RSUD dr. Drajat Prawiranegara Kamporin

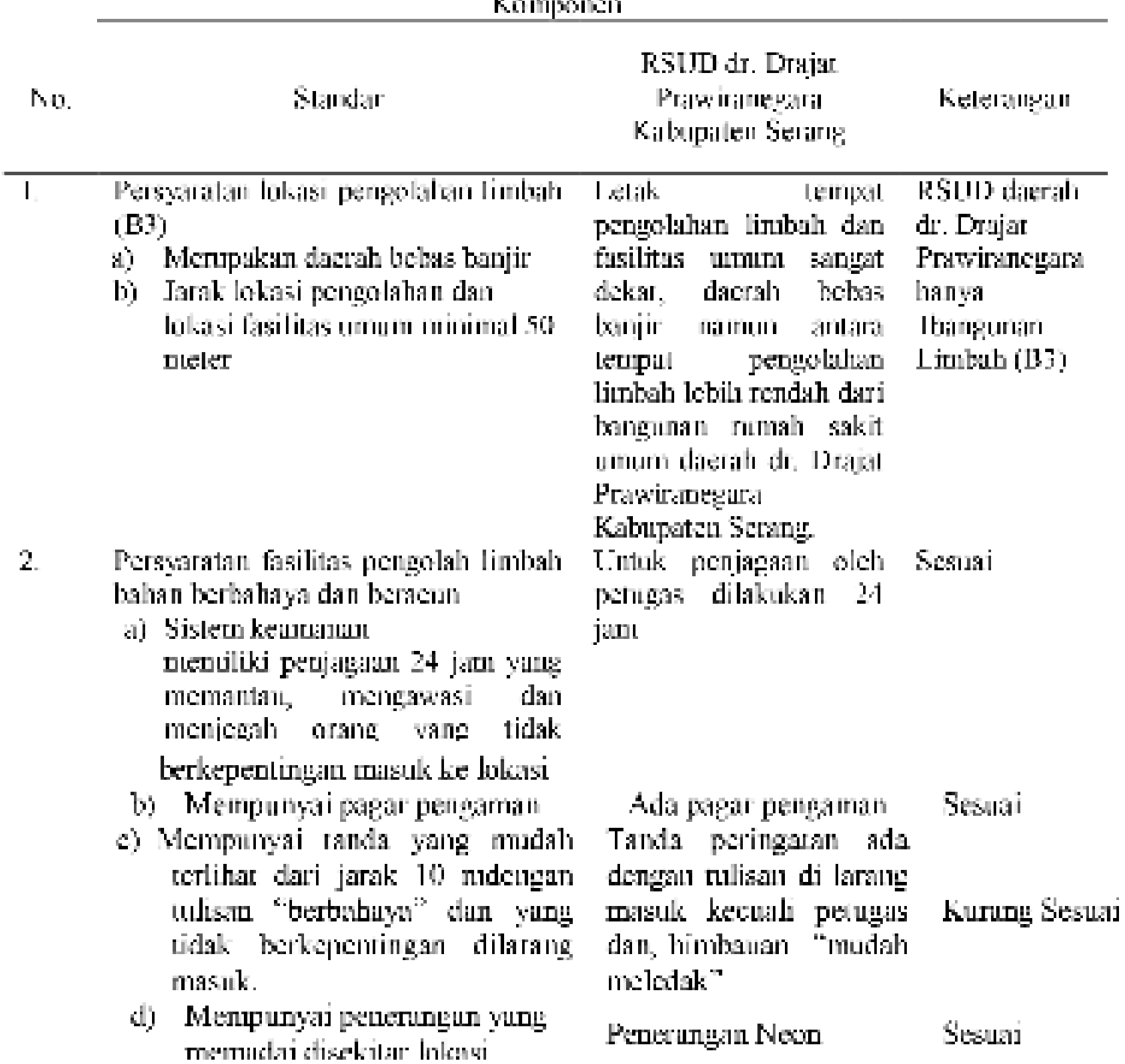


$3 . \quad$ Sistern turupibant lintxilı

a) Pengolahan limbah $B .3$ harus mempunyai rensana, dokunen tan pciunjuk teknis oprasi

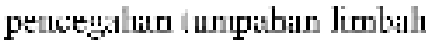

1. Sistem penangeulangan laeadsan darural

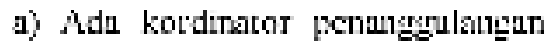
darurat yan hertancyoule jakab melalisanikan lindakan lindakan yang sesuai prosudur.

b) Jaringan kxmunikasi: pemberiubuan kepuda tila l.endlasu thaturst.

c) Mcmiliki mosudur crakuasi lugi sclund pelscrian fisilitas

d) Vermpunyili peraladar leroedial perangegulanganan keadaan darurat

c) Tersedianva neralaran dan baju pelindung, kegi selurul star pcnanğgntlanęan keaduan darurat di luk issi sesua i dengara jencis limbah yaner ditmenti

0) Melakukan yelatilian buy, karyswan dalam pestagentaugin kestaien danנrat.

5.
A Sisken pencesalun lerhadup kelxikiuiun

a) memasang sistem arde (elecincolingat smoupiding)

bi monusane jelus terlihat dur jarak $10 \mathrm{~m}$

c) menasang peralatan pendeleksi bilkswil kebilkaran ynto bekerja setars olomat is ₹clame 24 jam

d) Menanta iarak antana hanguman hangunan yang memudas schungga nobil kebukurun tnempunyai aloses neruju lokisi kelxikaran. lempisonge di

beleriapil

ruangall

Iunda prringaten uda Stoua

tentista tulisitu "lidak

bokh merokol."

Rumblı sakit unmm

therstb tr. Drsijalt

Priwiraneguri.

kalxuparen serang

memiliki alarm

ketxukurun.

Jarsk antara lemeunan kemungkinan dilahui mobil pemadan

bebukurun dan RSUD

dr. Traja. Pravinaresiara

kahupaicn scrang

tcrictak dipingeir jalan

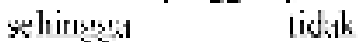

menyulitkin mobil

kehakaran bila terjadi

kehakaran

Rumsh Suki Lruus

Docrah di Draial

Pransirancgara

kubupation sorung tekil

tersedial peimjuk leknus

icrtang perawalan

amabila terjadi

Tumpuban dimlalı

Tordingtor

penengeulangau

keadnan singh tim K? yaner di bentuk RSLD dr. Traial Prayianesara Kabuparen Serang.

Torsodia telcpon yan dajxit mengirim berita

Ada prosudur crakuasi

Tersedial peralialiar kchakaran (APAR)

Ada alat pclindung diri epperli sorung. tarigan, scputu bost, nusker dan $\therefore$ AR

adia [pelation lerialdap penangrgntanıำ

bebukarau

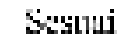

Pelialdand leulatue peralatan perlindungan twluk keildalan tharual d.11 P3K

2. Petalatun pelindin:

3. Pejalibulu ut.uk keidkian darisat
Stand

Sesuai

Sevuni

Scะua1

Sesuai

Sestisi

Sesuai
S'esum 
4. prusedur iospelast

5. K3

6. I'crituran peruendang undangan tentune penęelolusn limbah B.3

B. Pétalian klusus pemeliliafain

a. Peincliharaun peralatan pergokaban dan jeralatim perumbally.

b. Pergoprasian alia penoulalkir dus peralıus pexuṇịng

c. Liburalcorium

Prosidur pensinpunan dubuturulisj Linbab datu pelapgoras.

C. Persyiffatan penanganan limbeh B. schelum diolih

a) 1)ilakkukiall uii inualis is kimia

b) Pensnousn pililun proses pengolialian limbiali $\mathrm{H}^{3}$ pemeriksaan oleh penanggung jawab (penghasil, pengumpul, pengolah). Rumah Sakit Umum Daerah dr. Drajat Prawiranegara Kabupaten Serang sudah melakukan pemeriksaan pada saat pengemasan, hal tersebut untuk menghindari dampak buruk limbah B3

d. Menurut Keputusan Kepala Bapedal No.01/tahun 1995 kemasan yang rusak diperlukan sebagai limbah B3 tetapi di Rumah Sakit Umum Daerah dr. Drajat Prawiranegara Kabupaten Serang kemasan tersebut disimpan dalam gudang yang tidak terpakai, seharunya pihak RSUD melakukukan pergantian berkala untuk menangani kemasan yang rusak

e. Menurut Keputusan Kepala Bapedal No. 01 tahun 1995 ruangan penyimpanan harus memiliki fasilitas peneranagan yang memadai untuk oprasional inspeksi rutin. Rumah Sakit Umum Daerah dr. Drajat Prawiranegara Kabupaten Serang memiliki penerangan namun kurang. Hal tersebut dikarenakan kurang adanya perhatian dari petugas terutama untuk pemeriksaan malam hari.

f. Menurut Keputusan Kepala Bapedal
Sutivtya pelatdaid

Adia peme libaralara pada peraliatus

Scลנהi

Tiduk

lidak anla pengujian"

męmiliaialat

Proges pengelulatir

dan bursum derlyan $P \%$.

Waslec

No. 01 tahun 1995 tempat penyimpanan untuk lebih dari karakteristik limbah B3. Tempat penyimpanan di Rumah Sakit Umum Daerah dr. Drajat Prawiranegara Kabupaten Serang tidak memiliki penyimpanan lebih dari satu. Hal ini dikarenakan hanya sebatas sementara pihak ke-3 PT. Wastec Internasional melakukan pengangkutan berkala 1 minggu $3 x$.

g. Menurut Keputusan Kepala Bapedal No. 01 tahun 1995 luas tanah termasuk bangunan penyimpanan dan fasilitas lainnya minimal 1 ha. Hal tersebut kurang sesuai peraturan. Karena limbah B3 langsung di kemas dan di angkut oleh PT. Wastec

h. Menurut Keputusan Kepala Bapedal No. 01 tahun 1995 adanya fasilitas darurat untuk menampung tumpahan cairan/bahan yang terkontaminasi limbah dalam jumlah besar. Di Rumah Sakit Umum Daerah dr Drajat Prawiranegara Kabupaten Serang fasilitas darurat tumpahan limbah B3 sesuai peraturan.

i. Menurut Keputusan Kepala Bapedal No. 01 tahun 1995 tata cara penyimpanan/pengumpulan. Tata cara 
pengemasan dan pengumpulan sesuai dengan peraturan.

j. Menurut Keputusan Kepala Bapedal No. 01 tahun 1995 kemasan yang digunakan plastik tertutup. Di Rumah Sakit Umum Daerah dr. Drajat Prawiranegara kemasan yang digunakan sesuai dengan peraturan. Strategi perencanaan pengelolaan limbah B3 di RSUD dr Drajat Prawiranegara Mencakup dari mulai pewadahan, pengumpulan, pengolahan dan pemusnahan.

Berdasarkan PP Nomor 101 Tahun 2014 Tentang Pengelolaan Limbah B3 di RSUD dr Drajat sebagaian sudah sesuai dengan PP Nomor 101, dan ada yang belum sesuai yang ke depannya akan ditindaklanjuti. Pada point $\mathrm{b}, \mathrm{c}, \mathrm{h}$ dan $\mathrm{i}$

\section{Kesimpulan}

Berdasarkan hasil penelitian tentang studi pengelolaan limbah bahan berbahaya dan beracun B3 di Rumah Sakit Umum Daerah dr. Drajat Prawiranegara Kabupaten Serang didapat simpulkan sebagai berikut:

1. Pada tahapan pengemasan, pengangkutan dan pengumpulan limbah medis padat sudah sesuai dengan peraturan Bapedal No. 01 tahun 1995. Namun pada tahap penyimpanan dan persyaratan bangunan tidak sesuai dengan peraturan.

2. Keputusan kepala Bapedal No: 02 tahun 1995 tentang dokumen limbah B3. Rumah Sakit Umum Daerah dr. Drajat Prawiranegara Kabupaten Serang sudah memiliki dokumen yang lengkap tentang limbah B3, Rumah Sakit Umum Daerah Kabupaten Serang sudah memiliki SOP pengelolaan limbah medis dan non medis dan pengelolaan limbah benda tajam.

3. Keputusan Kepala Bapedal No: 03 tahun 1995 tentang pengelolaan limbah B3

4. Keputusan Kepala Bapedal No 4 tahun 1995 tentang persyaratan penimbunan pengolahan Rumah Sakit Umum Daerah dr. Drajat Prawiranegara Kabupaten Serang tidak memiliki tempat pembuangan hasil akhir hasil insenerasi limbah B3

5. Keputusan Kepala Bapedal No 5 tahun 1995 tentang simbol dan label. Simbol limbah B3 yang digunakan Rumah Sakit Umum Daerah dr. Drajat Prawiranegara Kabupaten Serang hanya berada pada ruangan oksigen, farmasi dan laboratorium, dimana simbol tersebut di tempel di depan pintu masuk ruangan.

\section{Daftar Pustaka}

Anonymous, 2001, Peraturan Pemerintah RI No 74 Tahun 2001 tentang Bahan Berbahaya dan Beracun.

Imam Hendargo A. Ismoyo, 2009, Panduan Tata Cara Indentifikasi Limbah B3, Jakarta: Deputi IV MENLH Bidang Pengelolaan B3.

Keputusan Kepala Bapedal No. Kep-01/ BAPEDAL/09/1995 tentang tata cara dan persyaratan Teknis Penyimpanan dan Pengumpulan Limbah Bahan Berbahaya dan Beracun.

Keputusan Kepala Bapedal No. 2 Tahun 1995 tentang Dokumen Limbah Bahan Berbaya dan Beracun.

KeputusanBapedalNo.Kep-03/BAPEDAL/09/1995 tentang Persyaratan Teknis Pengelolaan Limbah Bahan Berbahaya dan Beracun.

Keputusan Kepala Bapedal No. 4 tahun 1995 tentang Tata Cara Persyaratan Penimbunan Hasil Pengolahan, Persyaratan LokasiBekas Pengolahan, dan Lokasi Bekas Penimbunan Limbah B3.

Keputusan Kepala Bapedal No. 5 Tahun 1995 Tentang Simbol dan Label Limbah B 3.

2008, Kajian Ulang Dokumen Upaya Pengelolaan Lingkungan Hidup dan Upaya Pemantauan Lingkungan Hidup Pengembangan RSUD.dr. Drajat Prawiranegara Kabupaten Serang. 